\title{
Perceptions of Organizational Change by Different Levels of Student Affairs Administrators
}

\author{
John C. Dickerson
}

Higher education is a profession constantly experiencing change. Students change, policies change, trends change, leaders change, organizational structures change; the only constant seems to be change itself. Due to the fact that limited research exists on the concept of organizational change in student affairs, this study was conducted to examine the concept of organizational change as perceived by different levels of student affairs administrators and to develop principles and guidelines for organizational change that parallel the mission of student affairs organizations.

The need for higher education to change and manage change is critical (Mancini, 1997). Change is an inevitable part of any vital educational enterprise (Barr \& Golseth, 1990). Administrators can either react to situations and circumstances that necessitate change, or they can actively pursue it (Henderson \& McAdam, 1998).

One component of higher education that has experienced dramatic change over the past few decades is student affairs. Beginning in the late 1800's, much of the responsibility for the social, affective, and moral development of students was transferred from college faculty to student personnel professionals (Garland \& Grace, 1993). The college literally served 'in the place of the parent,' a concept known as in-loco parentis (Matthews, 1999; Jones, 1988) from this time period until the 1970's (Upcraft \& Barr, 1990). The 1980's brought a more diverse student population, including an increase in the number of adult students (Belch \& Strange, 1995) and part-time students (Kuh, 1990). The 1990's brought a heterogeneous student body to campus (Levine \& Cureton, 1998), which led to institutions becoming a microcosm of the larger society, both locally and globally.

As new leaders and new students come to campuses, new needs will continue to emerge in student affairs organizations. Student affairs organizations, along with the rest of higher education, are being forced to examine and reexamine their mission and essential functions to determine if they are necessary, and if so, whether or not they are meeting the needs that they are designed to meet (Kuh, 1996).

Today's context for higher education presents student affairs with challenges such as new technology, changing demographics, rising tuition costs, and concern for the moral and ethical climate of campus (Blimling \& Whitt, 1998). Sandeen (1996) reported that student affairs organizations are also faced with diminishing financial support, privatization of services, accountability, assessment, and liability. Mancini (1997) indicated that more non-traditional students continue to enroll, federal and state funding are decreasing, student populations are declining in number, and programs and departments are being consolidated and/or eliminated.

John C. Dickerson, EdD, is the Assistant Dean for Judicial Affairs and Mediation Services at Middle Tennessee State University. 
These challenges will lead to changes within student affairs organizations. Shaffer (1993) reported that student affairs will be responsible for leading the change process for higher education. The problem that exists is that there is limited literature concerning organizational change in higher education and student affairs. More research needs to be concentrated in this area in order to develop principles and guidelines for organizational change that parallel the mission of student affairs organizations. The purpose for conducting the current study was to examine the concept of organizational change as perceived by student affairs administrators and to develop recommendations for change management based on these perceptions. The study examined one null hypothesis and one research question. The null hypothesis was: There will be no significant difference $(p>.05)$ in the perceptions of organizational change by different levels of student affairs administrators. The research question asked was: What are the perceptions of organizational change among student affairs administrators in higher education?

\section{Research Procedures}

The study used a quantitative research design. Specifically, a survey research design was employed for the study. Descriptive statistics, as well as inferential statistical methods, were employed to analyze data. All data related to the study were gathered through the use of a researcher-designed survey instrument (the instrument is summarized as part of Table 2). Due to the fact that some conference attendees chose not to participate in the study, inferential statistics were used in order to generalize the results of the sample to the entire population.

The survey instrument was divided into two sections. Section 1 requested demographic data and section 2 contained questions used to gather data on the administrator's perceptions on organizational change at their institution. Section 2 of the survey was divided into three subsections: a subsection on planning organizational change, a subsection on implementing organizational change, and a subsection on evaluating organizational change. The survey contained a total of 35 questions. The survey instrument was a Likert-type scale of 1-5, where 1 represented strong disagreement, 3 represented neutral perceptions, and 5 represented strong agreement. An advantage of using the Likert-type scale is that it is relatively quick to develop, yet the reliability has been similar to that of other methods that take longer to develop (Best \& Kahn, 1998).

A committee of three judges established content validity of the survey. Each judge was sent a letter explaining the purpose of the study, the qualifications for being a judge, and what was necessary for content validity for the study. Best and Kahn (1998) wrote "basic to the validity of a questionnaire is asking the right questions in the least ambiguous way" (p. 310). The criteria for meeting content validity for this study were the questions on the survey had to be clear, precise, and related to the content of the study. Each judge provided a letter affirming the content validity of the survey instrument.

The survey was distributed at the Southern Association for College Student Affairs 
(SACSA) Conference between the dates of November 6, 1999 and November 8, 1999. A total of 308 individuals pre-registered for the conference. However, 57 of these individuals were not current student affairs administrators, thus they were not able to participate in the study, reducing the total sample size to 251 individuals. Distribution occurred by including the survey to a packet of information that all attendees received upon arrival to the conference. A cover letter and the operational definitions of each level of administrator were attached with each questionnaire advising the participants of the purpose of the study, giving directions on completing the survey, and advising each participant that participation in the study was voluntary. Surveys were collected at the conference by having participants return the survey to the registration table. Participants were also invited to leave their business card if they were interested in obtaining the results of the study (the business card was not attached to the survey in order to ensure anonymity). An attempt was made to collect data from at least $60 \%$ of the eligible conference attendees. Due to the fact that the desired response rate was not achieved after the first distribution, a second copy of the materials was mailed to each eligible individual.

\section{Data Analysis}

The null hypothesis for the study was tested through a one-way analysis of variance (ANOVA) using a .05 level of significance. A Tukey computation (.05 significance level) was used as a post-hoc test to identify exactly where differences existed among each level of administration. Percentages and frequencies were utilized in analyzing the data for the research question. The null hypothesis was analyzed in three separate sections: the planning of organizational change (questions 5-18), the implementation of organizational change (questions 19-28), and the evaluation of organizational change (questions 29-35). The questions were grouped together in sections rather than analyzing each question individually to reduce the risk of Type I error. Type I error is rejecting the null hypothesis when it should be accepted (Gall, Borg, \& Gall, 1996). Data from all three levels of administrators were used to analyze the hypothesis and research question. Table 1 provides an illustration of the results of the one-way ANOVA. Table 2 illustrates the percentage of responses by each level of administration for each question on the survey.

\section{Results}

A total of 40 surveys were obtained through the conference distribution and a total of 145 surveys were obtained through the mail-out distribution. The total response rate for the study was $74.5 \%$ (185 surveys). After eliminating all unusable instruments, a total of 144 surveys ( $77.5 \%$ of all the surveys returned) were used in the data analysis ( 36 from the conference distribution and 108 from the mail-out distribution). Table 3 reflects the number and percentage of respondents by each level of administration. After results were compiled, each participant requesting results of the study received a debriefing letter via e-mail outlining the results of the study. 


\section{Summary of Findings - Null Hypothesis}

Results indicated that significant difference existed among different levels of student affairs administrators regarding their perceptions of planning organizational change (.020 level of significance) and implementing organizational change (.018 level of significance), thus the null hypothesis was rejected for these two sub-sections. The Tukey computation showed that the significant difference existed between senior-level and entry-level administrators concerning their perceptions of planning organizational change (.013 level of significance) and implementing organizational change (.013 level of significance). No significant difference existed among student affairs administrators regarding their perceptions of evaluating organizational change (.955 level of significance), thus the null hypothesis was accepted for this sub-section.

\section{Summary of Findings - Research Question}

All three levels of administration agreed that organizational change was necessary in their institution. They also reported that that the change they had experienced was based on organizational needs. Radical organizational change was not occurring within their organization. Ideas for change were generated from within, generally at the senior level of administration. Senior level administrators did not feel employees were likely to resist change whereas both mid-level and entry level administrators felt that employees would resist change. All three levels believed that organizational change is a political process and that employees at any level could be influential in the politics of an organization. There were also a lack of effective procedures in place to help employees deal with the stress created by the change. Strategies for overcoming employee's resistance to change were lacking. However, employees were encouraged to give feedback concerning planned change.

All three levels of administrators indicated that they must work on developing their change management skills. All levels also reported that a change agent must be politically skilled or they would fail in instituting the desired change initiatives. Most individuals believed that their institution had adequate resources for implementing the desired change. Each level reported that it was essential for the change vision to be transferred into specific strategies for implementing the change process. All three levels also reported that their institutions utilized employees in implementing change. However, there was a lack of consensus regarding the communication of employee expectations in the implementation of the change. Change was implemented internally by combining change roles with existing job responsibilities.

Senior level administrators indicated that past change at their institution had been successful, while mid-level and entry level administrators were divided concerning the success of past change. All three levels reported that past change at their institution had been assessed based on the results it produced. All three levels also reported that there was no tendency for their organization to drift back to the status quo after the change had occurred. Mid-level administrators and entry level administrators felt that a systematic form for evaluating the change was lacking, whereas senior level administrators were 
divided on this issue.

\section{Discussion}

Study results suggest that senior-level administrators should work more closely with entry-level administrators when planning and implementing organizational change. Rogers and Ballard (1995) conducted a review of literature that showed that the individuals implementing the change have little impact on the success. They also reported that success in implementing change was dependent on the relationship between members of an organization. In other words, senior level administrators (those responsible for the change process) must utilize and involve all employees in the organization, including entry level administrators, in all levels of the change process. Knowing that there is a gap, student affairs offices need to work to overcome it.

While all three levels agreed that change was necessary, effective communication appeared to be lacking. Communication of the organizational change must exist between all levels of administration. Hurley (1998) argued that clear communication is an element that adds credibility to the change. According to Beckhard and Harris (1987), it is just as essential to communicate the desired future state of the change. Effective two-way communication among all three levels, specifically senior-level administrators and entry level administrators, is needed. Communication must occur between the change agent and employees, as well between the employees and the change agent (Cartwright, Andrews, \& Webley, 1999).

Change will be resisted in some form or another. Addressing the stress brought on by change is essential for developing positive attitudes towards change. Effective communication and involvement in the entire change process will reduce stress and negative resistance. Resistance in itself is not negative; when the resistance becomes excessive, it becomes detrimental to the implementation of change initiatives. In order to reduce negative resistance, it is important to manage the politics associated with organizational change and to also ensure that the planned change is in response to identifiable organizational needs.

Based on the literature review and the results of this study, the following strategies for instituting change in a student affairs environment are recommended:

q Involve and utilize all employees of the organization in the entire change process. All employees should be involved in the planning of change, the implementation of change, and the evaluation of change. Involvement leads to less resistance and also helps to manage the stress caused by organizational change.

q Develop a vision for the organization. Set organizational goals and prioritize them in order of importance. Begin creating and planning a change process.

q Create strategies for implementing change across the organization. Set a timeline for each strategy to be completed. Be sure to consider the needs of all employees, as well as ways to decrease resistance and stress. Also, develop a plan to evaluate the effectiveness of the change weekly, monthly, and annually. 
q Communicate during all phases of the change process (planning, implementation, and evaluation). Encourage employees to give feedback throughout the entire process. Keep employees well informed during all phases of the change process. Also, be sure to update all employees on a regular basis on the status of the change process. Scheduling a regular meeting to provide updates and inviting all employees to attend is recommended.

q Spread out the responsibilities as evenly as possible among all employees. Otherwise, some employees may get burned out quickly. Employees are still expected to complete their regular responsibilities, so be careful not to overload anyone.

q Evaluate all phases of the change process. How did the planning go? Was the change implemented smoothly? Was the change necessary? Did the change accomplish the intended result? Be sure to evaluate the effectiveness of the change on the entire organization. Develop a systematic plan for measuring the impact the change has on both the employees and the organization.

The current study creates a base that further research on organizational change in student affairs can add to. Further research should be conducted with the neutral variable on the survey eliminated. A scale of importance should be developed for each strategy. An individual may agree or disagree with a statement, but it may be unimportant to them. Further research concerning the impact of organizational change on a student affairs environment should be conducted in order to discover what type of changes need to take place. Further research should be undertaken to determine where the specific differences exist between senior-level and entry level administrators. Further research should also focus on national student affairs offices rather than only those in the southeastern United States.

\section{References}

Barr, M., \& Golseth, A. (1990). Managing change in a paradoxical environment. In M. Barr, M. Upcraft, \& Associates (Eds.), New Futures for Student Affairs (pp.201216). San Francisco: Jossey-Bass.

Beckhard, R., \& Harris, R. (1987). Organizational transitions. Needham Heights, MA: Addison-Wesley.

Belch, H., \& Strange, C. (1995). Views from the bottleneck: Middle managers in student affairs. NASPA Journal, 32(3) 208-222.

Best, J., \& Kahn, J. (1998). Research in education (8th ed.). Needham Heights, MA: Allyn \& Bacon.

Blimling, G., \& Whitt, E. (1998). Principles for good practice for student affairs. About Campus, 3(1), 10-15.

Cartwright, J., Andrews, T., \& Webley, P. (1999). A methodology for cultural measurement and change: A case study. Total Quality Management, 10, 121-125.

Gall, M., Borg, W., \& Gall, J. (1996). Educational research: An introduction (6th ed). 
New York: Longman.

Garland, P., \& Grace T. (1993). New perspectives for student affairs professionals: Evolving realities, responsibilities, and roles. ASHE-ERIC Higher Education Report Number 7. Washington, DC: George Washington University, School of Education and Human Development and ASHE/ERIC.

Henderson, J., \& McAdam, R. (1998). A more subjective approach to business improvement and organizational change. Total Quality Management, 9(4-5), 116-120.

Hurley, R. (1998). Managing change: An ethnographic approach to developing research propositions and understanding change in sales organizations. The Journal of Personal Selling and Sales Management, 18(3), 57-71.

Jones, P. (1988). Student services perspectives from a different point of view: Theory and application of fundamental coordination. NASPA Journal, 25(3), 213-217.

Kuh, G. (1996). Organizational theory. In S. Komives, P. Woodard, \& Associates (Eds.), Student Services: A Handbook for the Profession (3rd ed.) (pp. 269-294). San Francisco: Jossey-Bass.

Kuh, G. (1990). The demographic juggernaut. In M. Barr, M. Upcraft, \& Associates (Eds.), New Futures for Student Affairs (pp. 71-97). San Francisco: Jossey-Bass.

Levine, A., \& Cureton, J. (1998). When hope and fear collide: A portrait of today's college student. San Francisco: Jossey-Bass.

Mancini, C. (1997). On rugged ground: Managing change in the academic enterprise. Business Officer [Online]. Available online at www.nacubo.org/website/members/bomag/org_0697.

Matthews, A. (1997). Bright college years: Inside the American campus today. New York: Simon and Schuster.

Rogers, J., \& Ballard, S. (1995). Aspirational management: Building effective organizations through shared values. NASPA Journal, 32(3), 162-178.

Sandeen, A. (1996). Organization, functions, and standards of practice. In S. Komives, P. Woodard, \& Associates (Eds.), Student Services: A Handbook for the Profession (3rd ed.) (pp. 435-457). San Francisco: Jossey-Bass.

Shaffer, R. (1993). Wither student personnel work from 1968-2018? A 1993 retrospective. NASPA Journal, 30(3), 162-168.

Upcraft, M., \& Barr, M. (1990). Identifying challenges for the future in current practice. In M. Barr, M. Upcraft, \& Associates (Eds.), New Futures for Student Affairs (pp.3-21). San Francisco: Jossey-Bass. 
One-way ANOVA Results on Perceptions of Organizational Change

\begin{tabular}{lll} 
Section & F & Calc \\
\hline Planning of org. change & 4.045 & .020 \\
Implementing org. change & 4.132 & .018 \\
Evaluating org. change & 0.046 & .955
\end{tabular}

TABLE 2

Percentage of Responses to each Survey Question

\begin{tabular}{|c|c|c|c|c|c|c|}
\hline Question & Level & SD & D & $\mathbf{N}$ & A & SA \\
\hline \multirow{3}{*}{$\begin{array}{l}\text { Change dictated by } \\
\text { control outside of } \\
\text { senior management }\end{array}$} & Senior & 2.1 & 2.1 & 6.4 & 42.6 & 46.8 \\
\hline & Mid & 0.0 & 3.0 & 7.6 & 39.4 & 50.0 \\
\hline & Entry & 3.2 & 12.9 & 12.9 & 58.1 & 12.9 \\
\hline \multirow{3}{*}{$\begin{array}{l}\text { Commitment to } \\
\text { employees when } \\
\text { implementing change }\end{array}$} & Senior & 6.4 & 6.4 & 31.9 & 53.2 & 2.1 \\
\hline & Mid & 7.6 & 31.8 & 22.7 & 33.3 & 4.5 \\
\hline & Entry & 3.2 & 38.7 & 29.0 & 25.8 & 3.2 \\
\hline \multirow{3}{*}{$\begin{array}{l}\text { Change based on } \\
\text { organizational } \\
\text { needs }\end{array}$} & Senior & 6.4 & 12.8 & 12.8 & 46.8 & 21.3 \\
\hline & Mid & 3.0 & 21.2 & 25.8 & 40.9 & 9.1 \\
\hline & Entry & 0.0 & 22.6 & 22.6 & 45.2 & 9.7 \\
\hline \multirow{3}{*}{$\begin{array}{l}\text { Effective stress } \\
\text { management } \\
\text { procedures in place }\end{array}$} & Senior & 6.4 & 40.4 & 38.3 & 14.9 & 0.0 \\
\hline & Mid & 13.6 & 48.5 & 18.2 & 18.2 & 1.5 \\
\hline & Entry & 3.2 & 61.3 & 25.8 & 9.7 & 0.0 \\
\hline \multirow{3}{*}{$\begin{array}{l}\text { Ideas for change } \\
\text { generated } \\
\text { internally }\end{array}$} & Senior & 2.1 & 14.9 & 8.5 & 40.4 & 34.0 \\
\hline & Mid & 3.0 & 16.7 & 16.7 & 43.9 & 19.7 \\
\hline & Entry & 0.0 & 12.9 & 12.9 & 64.5 & 9.7 \\
\hline \multirow{3}{*}{$\begin{array}{l}\text { Employee feedback } \\
\text { about change is } \\
\text { encouraged }\end{array}$} & Senior & 4.3 & 4.3 & 21.3 & 66.0 & 4.3 \\
\hline & Mid & 7.6 & 24.2 & 15.2 & 40.9 & 12.1 \\
\hline & Entry & 3.2 & 38.7 & 16.1 & 32.3 & 9.7 \\
\hline \multirow{3}{*}{$\begin{array}{l}\text { Plans to overcome } \\
\text { employee resistance } \\
\text { in place first }\end{array}$} & Senior & 8.5 & 38.3 & 27.7 & 23.4 & 2.1 \\
\hline & Mid & 15.2 & 43.9 & 19.7 & 16.7 & 4.5 \\
\hline & Entry & 6.5 & 54.8 & 22.6 & 16.1 & 0.0 \\
\hline \multirow{3}{*}{$\begin{array}{l}\text { Org. change is } \\
\text { necessary because } \\
\text { of societal change }\end{array}$} & Senior & 19.1 & 40.4 & 12.8 & 14.9 & 12.8 \\
\hline & Mid & 15.2 & 39.4 & 15.2 & 22.7 & 7.6 \\
\hline & Entry & 16.1 & 35.5 & 16.1 & 25.8 & 6.5 \\
\hline
\end{tabular}




\begin{tabular}{|c|c|c|c|c|c|c|}
\hline Question & Level & SD & D & $\mathbf{N}$ & $\mathbf{A}$ & $\mathbf{S A}$ \\
\hline \multirow{3}{*}{$\begin{array}{l}\text { Employees are used } \\
\text { to develop change } \\
\text { initiatives }\end{array}$} & Senior & 0.0 & 8.5 & 17.0 & 61.7 & 12.8 \\
\hline & Mid & 4.5 & 19.7 & 15.2 & 48.5 & 12.1 \\
\hline & Entry & 6.5 & 25.8 & 29.0 & 32.3 & 6.5 \\
\hline \multirow{3}{*}{$\begin{array}{l}\text { Employees more } \\
\text { likely to resist } \\
\text { than embrace change }\end{array}$} & Senior & 4.3 & 40.4 & 25.5 & 19.1 & 10.6 \\
\hline & Mid & 7.6 & 13.6 & 25.8 & 39.4 & 13.6 \\
\hline & Entry & 0.0 & 29.0 & 29.0 & 38.7 & 3.2 \\
\hline \multirow{3}{*}{$\begin{array}{l}\text { Change is a } \\
\text { political process }\end{array}$} & Senior & 2.1 & 8.5 & 19.1 & 48.9 & 21.3 \\
\hline & Mid & 0.0 & 7.6 & 12.1 & 48.5 & 31.8 \\
\hline & Entry & 0.0 & 0.0 & 9.7 & 58.1 & 32.3 \\
\hline \multirow{3}{*}{$\begin{array}{l}\text { Any level employee } \\
\text { can influence } \\
\text { organizational politics }\end{array}$} & Senior & 4.3 & 12.8 & 8.5 & 51.1 & 23.4 \\
\hline & Mid & 3.0 & 24.2 & 12.1 & 43.9 & 16.7 \\
\hline & Entry & 0.0 & 22.6 & 29.0 & 48.4 & 0.0 \\
\hline \multirow{3}{*}{$\begin{array}{l}\text { Managing change is } \\
\text { really about } \\
\text { managing stakeholders }\end{array}$} & Senior & 2.1 & 8.5 & 21.3 & 44.7 & 23.4 \\
\hline & Mid & 3.0 & 7.6 & 13.6 & 54.5 & 21.2 \\
\hline & Entry & 0.0 & 12.9 & 29.0 & 54.8 & 3.2 \\
\hline \multirow{3}{*}{$\begin{array}{l}\text { More complex the } \\
\text { organization, more } \\
\text { complex the politics }\end{array}$} & Senior & 2.1 & 6.4 & 17.0 & 42.6 & 31.9 \\
\hline & Mid & 0.0 & 13.6 & 9.1 & 47.0 & 30.3 \\
\hline & Entry & 0.0 & 6.5 & 12.9 & 54.8 & 25.8 \\
\hline \multirow{3}{*}{$\begin{array}{l}\text { Change vision is } \\
\text { translated into } \\
\text { relevant strategies }\end{array}$} & Senior & 2.1 & 8.5 & 14.9 & 63.8 & 10.6 \\
\hline & Mid & 4.5 & 15.2 & 16.7 & 50.0 & 13.6 \\
\hline & Entry & 0.0 & 19.4 & 22.6 & 58.1 & 0.0 \\
\hline \multirow{3}{*}{$\begin{array}{l}\text { Employees are used } \\
\text { in change } \\
\text { implementation }\end{array}$} & Senior & 0.0 & 6.4 & 10.6 & 66.0 & 17.0 \\
\hline & Mid & 1.5 & 18.2 & 13.6 & 53.0 & 13.6 \\
\hline & Entry & 0.0 & 16.1 & 25.8 & 54.8 & 3.2 \\
\hline \multirow{3}{*}{$\begin{array}{l}\text { Expectations about } \\
\text { change implementation } \\
\text { communicated clearly }\end{array}$} & Senior & 4.3 & 10.6 & 23.4 & 55.3 & 6.4 \\
\hline & Mid & 4.5 & 39.4 & 24.2 & 22.7 & 9.1 \\
\hline & Entry & 6.5 & 41.9 & 22.6 & 29.0 & 0.0 \\
\hline \multirow{3}{*}{$\begin{array}{l}\text { Employees told about } \\
\text { effects of change } \\
\text { organizationally }\end{array}$} & Senior & 0.0 & 19.1 & 25.5 & 46.8 & 8.5 \\
\hline & Mid & 7.6 & 28.8 & 18.2 & 39.4 & 6.1 \\
\hline & Entry & 6.5 & 45.2 & 29.0 & 19.4 & 0.0 \\
\hline \multirow{3}{*}{$\begin{array}{l}\text { Employees told about } \\
\text { effects of change } \\
\text { personally }\end{array}$} & Senior & 4.3 & 19.1 & 27.7 & 42.6 & 6.4 \\
\hline & Mid & 9.1 & 37.9 & 19.7 & 27.3 & 6.1 \\
\hline & Entry & 3.2 & 48.4 & 25.8 & 22.6 & 0.0 \\
\hline \multirow{3}{*}{$\begin{array}{l}\text { Organization has } \\
\text { adequate resources } \\
\text { to change }\end{array}$} & Senior & 10.6 & 10.6 & 25.5 & 51.1 & 2.1 \\
\hline & Mid & 9.1 & 25.8 & 28.8 & 34.8 & 1.5 \\
\hline & Entry & 0.0 & 25.8 & 41.9 & 32.3 & 0.0 \\
\hline
\end{tabular}




\begin{tabular}{|c|c|c|c|c|c|c|}
\hline Question & Level & SD & D & $\mathbf{N}$ & $\mathbf{A}$ & $\mathbf{S A}$ \\
\hline \multirow{3}{*}{$\begin{array}{l}\text { Combine change roles } \\
\text { with existing job } \\
\text { responsibilities }\end{array}$} & Senior & 0.0 & 17.1 & 25.5 & 57.4 & 0.0 \\
\hline & Mid & 3.0 & 3.0 & 24.2 & 57.6 & 12.1 \\
\hline & Entry & 0.0 & 9.7 & 35.5 & 51.6 & 3.2 \\
\hline \multirow{3}{*}{$\begin{array}{l}\text { Organization tends } \\
\text { to go through } \\
\text { radical change }\end{array}$} & Senior & 19.1 & 51.1 & 14.9 & 12.8 & 2.1 \\
\hline & Mid & 6.1 & 50.0 & 15.2 & 19.7 & 9.1 \\
\hline & Entry & 9.7 & 38.7 & 22.6 & 22.6 & 6.5 \\
\hline \multirow{3}{*}{$\begin{array}{l}\text { Administrators need } \\
\text { change management } \\
\text { skills }\end{array}$} & Senior & 0.0 & 0.0 & 14.9 & 48.9 & 36.2 \\
\hline & Mid & 3.0 & 0.0 & 15.2 & 39.4 & 42.4 \\
\hline & Entry & 0.0 & 3.2 & 3.2 & 64.5 & 29.0 \\
\hline \multirow{3}{*}{$\begin{array}{l}\text { Change agent needs } \\
\text { political skills or } \\
\text { will fail }\end{array}$} & Senior & 0.0 & 4.3 & 23.4 & 44.7 & 27.7 \\
\hline & Mid & 0.0 & 13.6 & 19.7 & 36.4 & 30.3 \\
\hline & Entry & 3.2 & 6.5 & 29.0 & 45.2 & 16.1 \\
\hline \multirow{3}{*}{$\begin{array}{l}\text { Most prior } \\
\text { organizational change has } \\
\text { been successful }\end{array}$} & Senior & 0.0 & 10.6 & 21.3 & 59.6 & 8.5 \\
\hline & Mid & 4.5 & 18.2 & 31.8 & 37.9 & 7.6 \\
\hline & Entry & 0.0 & 9.7 & 41.9 & 45.2 & 3.2 \\
\hline \multirow{3}{*}{$\begin{array}{l}\text { Effectiveness of } \\
\text { change has been } \\
\text { difficult to assess }\end{array}$} & Senior & 4.3 & 31.9 & 27.7 & 29.8 & 6.4 \\
\hline & Mid & 4.5 & 24.2 & 27.3 & 34.8 & 9.1 \\
\hline & Entry & 0.0 & 12.9 & 41.9 & 41.9 & 3.2 \\
\hline \multirow{3}{*}{$\begin{array}{l}\text { No systematic form } \\
\text { of change evaluation } \\
\text { in organization }\end{array}$} & Senior & 14.9 & 42.6 & 10.6 & 31.9 & 0.0 \\
\hline & Mid & 19.7 & 42.4 & 18.2 & 13.6 & 6.1 \\
\hline & Entry & 9.7 & 64.5 & 12.9 & 12.9 & 0.0 \\
\hline \multirow{3}{*}{$\begin{array}{l}\text { Employees are } \\
\text { fatigued by rate of } \\
\text { change }\end{array}$} & Senior & 8.5 & 40.4 & 21.3 & 23.4 & 6.4 \\
\hline & Mid & 3.0 & 30.3 & 24.2 & 30.3 & 12.1 \\
\hline & Entry & 0.0 & 32.3 & 22.6 & 35.5 & 9.7 \\
\hline \multirow{3}{*}{$\begin{array}{l}\text { Change is taken for } \\
\text { granted in our } \\
\text { organization }\end{array}$} & Senior & 2.1 & 38.3 & 27.7 & 29.8 & 2.1 \\
\hline & Mid & 6.1 & 33.3 & 36.4 & 22.7 & 1.5 \\
\hline & Entry & 0.0 & 25.8 & 45.2 & 25.8 & 3.2 \\
\hline \multirow{3}{*}{$\begin{array}{l}\text { Tried to implement } \\
\text { change, but status } \\
\text { quo is maintained }\end{array}$} & Senior & 6.4 & 44.7 & 25.5 & 19.1 & 4.3 \\
\hline & Mid & 9.1 & 45.5 & 10.6 & 24.2 & 10.6 \\
\hline & Entry & 0.0 & 48.4 & 32.3 & 19.4 & 0.0 \\
\hline \multirow{3}{*}{$\begin{array}{l}\text { Change is assessed } \\
\text { on the results it } \\
\text { produces }\end{array}$} & Senior & 4.3 & 17.0 & 23.4 & 53.2 & 2.1 \\
\hline & Mid & 12.1 & 21.2 & 15.2 & 50.0 & 1.5 \\
\hline & Entry & 0.0 & 25.8 & 32.3 & 41.9 & 0.0 \\
\hline
\end{tabular}


TABLE 3

Respondents by Level of Administration

\begin{tabular}{lll} 
Level & Respondents $(\#)$ & Respondents $(\%)$ \\
\hline Senior & 47 & 32.6 \\
Mid & 66 & 45.8 \\
Entry & 31 & 21.6 \\
\hline
\end{tabular}

